\title{
Meningkatkan Aktivitas Belajar Ilmu Pengetahuan Sosial melalui Penerapan Strategi Injeksi pada Siswa Kelas IV SD Negeri 028228 Binjai TP 2016/2017
}

\author{
Diakoni Ginting \\ Guru SD Negeri 028228 \\ diakoniginting@gmail.com
}

\begin{abstract}
ABSTRAK
Ilmu Pengetahuan Sosial merupakan mata pelajaran yang mempersiapkan anak didik menjadi warga negara yang baik berdasarkan Pancasila dan UUD 1945, sehingga menumbuhkan dan memiliki mental yang baik untuk dapat melaksanakan kegiatan pembangunan. Tujuan penelitian tindakan kelas ini secara khusus adalah untuk meningkatkan aktivitas belajar Ilmu Pengetahuan Sosial pada siswa Kelas IV SD Negeri 028228 Binjai dengan menggunakan strategi Injeksi. Penelitian tindakan kelas ini dilaksanakan dengan menggunakan dua siklus, sedangkan masing-masing siklus terdiri dari dua kali pertemuan. Data dalam penelitian ini berupa kegiatan guru, aktivitas belajar siswa, respons siswa dalam kegiatan belajar mengajar, dan hasil evaluasi belajar. Pengumpulan data dalam penelitian ini menggunakan observasi/pengamatan, angket, wawancara, dan dokumentasi. Hasil evaluasi menunjukkan terdapat kenaikkan yang tuntas belajar dari 25 siswa $(65,79 \%)$ pada pra tindakan menjadi 30 siswa $(78,95 \%)$ pada Siklus I, dan menjadi 33 siswa $(86,84 \%)$ pada Siklus II. Sedangkan yang belum tuntas belajar mengalami penurunan dari 13 siswa $(34,21 \%)$ pada pra tindakan menjadi 8 siswa $(21,05 \%)$ pada Siklus I, dan menjadi 5 siswa $(13,16 \%)$ pada Siklus II.
\end{abstract}

Kata kunci: Strategi injeksi, aktivitas belajar, ilmu pengetahuan sosial.

\section{PENDAHULUAN}

Penyelenggaraan pendidikan merupakan tanggung jawab bersama antara pemerintah, masyarakat dan keluarga. Masing-masing memiliki peran yang sangat besar dalam rangka mewujudkan tujuan pendidikan. Keberhasilan penyelenggaraan pendidikan merupakan keberhasilan bersama. Tidak bisa salah satu pihak menyatakan dirinya sebagai yang paling berhasil dalam penyelenggaraan pendidikan.

SD Negeri 028228 Binjai merupakan salah satu sekolah dengan kondisi yang relatif terbatas. Kemampuan siswa, kepedulian orang tua, dan kondisi masyarakat, kurang dapat maksimal dalam mendukung penyelenggaraan pendidikan di sekolah. Sehingga dalam proses penyelenggaraan pendidikan 
kurang dapat dilaksanakan secara maksimal. Melihat kondisi riil di sekolah dan memahami tujuan yang diharapkan dalam pembelajaran Ilmu Pengetahuan Sosial, perlu dilakukan upaya secara serius dan terus menerus agar kegiatan pembelajaran dapat berjalan dengan baik. Aktivitas belajar semakin meningkat dan prestasi belajar siswa juga semakin sesuai dengan yang diharapkan semua pihak. Kondisi tersebut terutama terjadi pada siswa kelas IV SD Negeri 028228 Binjai, Kota Binjai Propinsi Sumatera Utara pada semester ganjil tahun pelajaran 2016/2017. Sehingga diperlukan usaha dari guru untuk dapat meningkatkan aktivitas belajar siswa dengan jalan memilih metode atau strategi pembelajaran yang tepat.

Untuk dapat meningkatkan aktivitas siswa dalam mengikuti kegiatan belajar mengajar, dan mendorong siswa selalu aktif dan kreatif dalam belajar, maka perlu strategi yang tepat. Strategi yang digunakan untuk mengatasi masalah tersebut adalah dengan strategi Injeksi. Strategi Injeksi merupakan strategi pembelajaran yang dirancang secara khusus untuk memberikan terapi atas kemalasan siswa dalam mengikuti kegiatan belajar mengajar di kelas. Teknik ini diberikan dengan jalan memberikan tugas-tugas tambahan yang harus dilakukan oleh siswa apabila dalam proses belajar mengajar ada siswa yang malas atau kurang bergairah dalam mengikuti pelajaran. Tugas-tugas ini diharapkan dapat memberikan kejutan kepada siswa yang malas, sehingga berusaha dengan cepat untuk dapat menyesuaikan diri dengan temantemannya yang lain. Dampak strategi Injeksi ini adalah siswa akan selalu berusaha untuk menyiapkan diri sebaik-baiknya dalam mengikuti kegiatan belajar mengajar di sekolah.

\section{METODE DAN FOKUS PENELITIAN}

Dalam pelaksanaan penelitian tindakan kelas ini, penulis melakukan berbagai persiapan dengan langkah-langkah sebagai berikut:

1) Refleksi awal, peneliti mengidentifikasi permasalahan aktivitas belajar siswa dalam memahami konsep dasar materi pelajaran pada siswa kelas IV.

2) Penulis merumuskan permasalahan secara operasional yang relevan dengan rumusan masalah penelitian.

3) Penulis merumuskan hipotesis tindakan. Hipotesis tindakan ini bersifat tentatif, sehingga sangat mungkin akan mengalami perubahan sesuai dengan keadaan di lapangan.

4) Menetapkan dan merumuskan rancangan tindakan yang meliputi:

a) Menetapkan indikator-indikator tujuan pembelajaran dengan strategi Injeksi.

b) Menyusun rancangan strategi belajar mengajar dengan strategi Injeksi.

c) Menyusun metode dan alat perekam data yang berupa angket, catatan di lapangan, pedoman analisis, dokumen, dan catatan harian.

d) Menyusun rancangan pengolahan data, baik yang bersifat kualitatif maupun kuantitatif. 
e) Mempersiapkan penyusunan laporan hasil dari penelitian tindakan kelas yang dilakukan.

Pelaksanaan tindakan dan pengamatan dalam penelitian ini dibagi dalam 2 siklus. Setiap siklus dibagi dalam tiga kali pertemuan. Kegiatan pelaksanaan tindakan dalam setiap siklus, dibarengi dengan pengamatan yang dapat dilakukan sebagai berikut:

1) Guru melaksanakan desain pembelajaran dengan strategi Injeksi yang telah direncanakan.

2) Guru memberikan tugas kepada siswa untuk dilaksanakan dan membuat laporan tentang kegiatan yang dilakukan, baik secara individu maupun secara kelompok sesuai dengan tugasnya masing-masing.

3) Guru mempelajari laporan kegiatan yang dilakukan oleh siswa baik secara individu maupun kelompok dan memberikan penjelasan tambahan jika diperlukan.

4) Guru merekam data dan mengamati kegiatan siswa sesuai dengan laporan yang telah disusun dengan menggunakan alat perekam, pedoman pengamatan serta catatan lapangan.

Peneliti mengadakan telaah terhadap data-data hasil penelitian yang telah dilakukan, melalui: analisis, sintesis, pemaknaan, penjelasan, dan menyimpulkan. Hasil yang diperoleh berupa temuan tingkat efektifitas desain pembelajaran dengan strategi Injeksi yang telah dirancang, dan menginventarisir daftar permasalahan yang muncul di lapangan yang untuk selanjutnya dapat digunakan sebagai dasar untuk melakukan perencanaan pada kegiatan berikutnya.

Dalam penelitian ini ada beberapa instrumen yang digunakan untuk menjaring data penelitian, antara lain: pedoman observasi, dokumen, dan catatan lapangan. Instrument penelitian disusun secara fleksibel dengan harapan agar segala bentuk permasalahan yang mungkin timbul dapat dieliminir dan dapat dicarikan solusinya dengan cepat dan tepat. Teknik analisis data menggunakan teknik analisis data kualitatif. Secara garis besar kegiatan analisis data dilakukan dengan langkah-langkah sebagai berikut:

1) Menelaah seluruh data yang dikumpulkan. Penelaahan dilakukan dengan cara menganalisis, mensintesis, memaknai, menerangkan, dan membuat kesimpulan. Kegiatan penelaahan pada prinsipnya dilaksanakan sejak awal penjaringan data.

2) Mereduksi data yang didalamnya melibatkan kegiatan pengkategorian dan pengklasifikasian. Hasil yang diperoleh dapat berupa pola-pola dan kecenderungan-kecenderungan yang terjadi dalam pelaksanaan pembelajaran dengan strategi Injeksi.

3) Menyusun keterkaitan atau pengaruh dari strategi Injeksi dengan aktivitas belajar siswa.

4) Menyusun kesimpulan dari keterkaitan atau pengaruh yang ada. 
Strategi Injeksi tidak akan dapat dilakukan secara efektif bila tidak melalui persiapan yang matang. Konsep dan kondisi siswa harus benar-benar sudah siap. Penjelasan tentang tugas masing-masing siswa dalam kegiatan pembelajaran harus telah dipahami oleh siswa dengan benar. Selain itu penjabaran tugas yang harus dilakukan oleh siswa, baik secara individu maupun secara kelompok juga harus terarah. Jika tidak, maka hasil yang diperoleh tidak akan menjadi maksimal.

\section{HASIL DAN PEMBAHASAN}

Pembahasan dijabarkan dalam tiga kegiatan, yaitu: (1) kegiatan pra tindakan; (2) kegiatan tindakan Siklus I; dan (3) kegiatan tindakan Siklus II. Kegiatan pra tindakan yang dilakukan pada siswa kelas IV SD Negeri 028228 Kec. Binjai Selatan, menemukan permasalahan yaitu prestasi belajar siswa masih rendah, sebagaimana ditunjukkan dalam hasil evaluasi pada pra tindakan, bahwa siswa yang sudah tuntas belajar sebesar 19 siswa $(65,79 \%)$, dan yang belum tuntas belajar sebesar 21 siswa $(34,21 \%)$.

\section{Siklus I}

Pelaksanaan tindakan yang dilakukan pada Siklus I terdiri dari tiga (3) kali pertemuan, yang masing-masing pertemuan menggunakan waktu 90 menit. Jadi dalam Siklus I menggunakan waktu 270 menit. Perencanaan tindakan yang akan dilaksanakan dalam kegiatan pembelajaran pada Siklus I sebagai berikut:

Tabel 1. Perencanaan Pembelajaran Siklus I

\begin{tabular}{|c|c|c|c|}
\hline No & Komponen & Waktu & Kegiatan \\
\hline 1 & Kegiatan awal & 15 menit & $\begin{array}{l}\text { Mengadakan presensi kelas. } \\
\text { Guru menjelaskan tujuan pembelajaran. } \\
\text { Guru menjelaskan metode mengajar yang } \\
\text { digunakan. } \\
>\text { Guru memberikan motivasi kepada siswa. } \\
>\text { Guru mengadakan apersepsi. }\end{array}$ \\
\hline 2 & Kegiatan inti & 210 menit & $\begin{array}{l}\text { Guru membentuk kelompok, masing-masing } \\
\text { kelompok terdiri dari } 6 \text { siswa. Ada dua } \\
\text { kelompok yang beranggotakan } 7 \text { siswa. Jumlah } \\
\text { kelompok ada } 6 \text { kelompok. } \\
>\text { Guru memberikan tugas kepada masing-masing } \\
\text { kelompok. } \\
>\text { Siswa melakukan kerja kelompok. } \\
>\text { Guru memberikan tugas tambahan, baik secara } \\
\text { individu maupun secara kelompok. } \\
>\text { Guru membimbing kerja kelompok. } \\
>\text { Guru membimbing siswa dalam melakukan } \\
\text { presentasi. } \\
>\text { Guru membimbing tanya jawab. }\end{array}$ \\
\hline 3 & Kegiatan akhir & 15 menit & $>$ Guru membuat kesimpulan bersama siswa. \\
\hline 4 & Evaluasi & 30 menit & > Guru mengadakan evaluasi akhir Siklus I. \\
\hline
\end{tabular}


Pelaksanaan tindakan dalam Siklus I dilaksanakan dalam tiga kali pertemuan. Secara rinci pelaksanaannya sebagai berikut:

1) Kegiatan awal (15 menit)

- Guru mengadakan presensi kelas.

- Guru menjelaskan tujuan pembelajaran pada setiap pertemuan dalam Siklus I.

- Guru selalu menjelaskan metode yang digunakan pada setiap pertemuan dalam Siklus I.

- Guru memberikan motivasi kepada siswa dalam mengikuti kegiatan belajar mengajar pada setiap pertemuan dalam Siklus I.

- Guru mengadakan apersepsi dalam setiap pertemuan pada Siklus I.

2) Kegiatan Inti (210 menit)

- Guru membentuk kelompok, masing-masing kelompok mempunyai 6 anggota. Jumlah keseluruhan ada 6 kelompok. Ada dua kelompok yang memiliki anggota 7 siswa.

- Guru memberikan tugas yang berbeda kepada masing-masing kelompok.

- Siswa melakukan kerja kelompok.

- Guru membimbing siswa dalam kerja kelompok.

- Guru mengamati siswa, baik secara individu maupun secara kelompok.

- Guru menunjuk salah satu kelompok untuk melakukan presentasi.

- Guru membimbing siswa dalam melakukan presentasi.

- Kelompok yang lain memberikan tanggapan secara bergiliran.

- Guru memberikan tugas tambahan kepada 2 kelompok, yaitu kelompok 3 dan kelompok 6. Laporan dilakukan secara individu.

- Guru memberikan tugas secara individu 2 siswa dari kelompok 1, dan 3 siswa dari kelompok 5.

3) Kegiatan akhir (15 menit)

- Bersama-sama dengan siswa, guru membuat kesimpulan dalam setiap perte-muan dari kegiatan pembelajaran yang telah dilakukan.

4) Evaluasi (30 menit)

- Guru memberikan evaluasi untuk mengetahui prestasi belajar siswa pada pertemuan ke tiga akhir Siklus I.

Hasil pengamatan yang dilakukan oleh observer dan guru dapat dilihat dalam tabel sebagai berikut: 
Tabel 2. Rekapitulasi Hasil Observasi Kegiatan Guru Siklus I

\begin{tabular}{|c|l|c|c|}
\hline \multirow{2}{*}{ No } & \multirow{2}{*}{ Kegiatan } & \multicolumn{2}{|c|}{ Siklus I } \\
\cline { 3 - 4 } & & Jumlah & \% \\
\hline 1 & Perencanaan Pembelajaran & 21 & 85 \\
\hline 2 & Pelaksanaan Pembelajaran & 19 & 79,17 \\
\end{tabular}

Kegiatan pengamatan terhadap aktivitas siswa dilakukan oleh guru maupun observer/pengamat pada saat siswa melakukan diskusi. Berdasarkan hasil pengamatan aktivitas belajar siswa (lampiran 5), dapat dikemukakan sebagai berikut:

Tabel 3. Hasil Observasi Aktivitas Belajar Siswa Siklus I

\begin{tabular}{|c|c|c|c|c|c|}
\hline \multirow{2}{*}{ No } & \multirow{2}{*}{ Indikator } & \multicolumn{4}{|c|}{ Skala Penilaian } \\
\hline & & 1 & 2 & 3 & 4 \\
\hline 1 & Kehadiran siswa. & & & $\sqrt{ }$ & \\
\hline 2 & Perhatian terhadap materi pelajaran. & & & $\sqrt{ }$ & \\
\hline 3 & Semangat mengikuti pembelajaran. & & $\sqrt{ }$ & & \\
\hline 4 & $\begin{array}{l}\text { Persiapan yang dilakukan sebelum belajar } \\
\text { mengajar. }\end{array}$ & & $\sqrt{ }$ & & \\
\hline 5 & Pertanyaan-pertanyaan yang disampaikan. & & $\sqrt{ }$ & & \\
\hline 6 & Tanggapan atau jawaban atas pertanyaan guru. & & & $\sqrt{ }$ & \\
\hline 7 & Penyelesaian tugas-tugas yang diberikan. & & & $\sqrt{ }$ & \\
\hline & Jumlah & \multicolumn{4}{|c|}{18} \\
\hline & Prosentase & \multicolumn{4}{|c|}{$64,29 \%$} \\
\hline
\end{tabular}

Berdasarkan rekapitulasi hasil kuesioner respons siswa terhadap kegiatan belajar mengajar pada Siklus I, dapat diketahui prosentase respons siswa dalam pembelajaran sebagaimana dalam tabel berikut ini:

Tabel 4. Prosentase Hasil Kuesioner Respons Siswa Terhadap Kegiatan Belajar Mengajar pada Siklus I

\begin{tabular}{|c|l|r|r|r|}
\hline No & \multicolumn{1}{|c|}{ Keterangan } & \multicolumn{1}{c|}{ Jumlah } & \multicolumn{1}{c|}{$\begin{array}{c}\text { Skor } \\
\text { Mean }\end{array}$} \\
\hline 1 & Tidak senang & 0 & 0 & 0 \\
\hline 2 & Kurang senang & 13 & 34,21 & 0,68 \\
\hline 3 & Senang & 12 & 52,63 & 1,58 \\
\hline 4 & Senang Sekali & 5 & 13,16 & 0,53 \\
\hline Jumlah & 30 & 100 & 2,79 \\
\hline
\end{tabular}

Berdasarkan hasil evaluasi pada Siklus I, siswa yang sudah tuntas belajar 6 siswa (78,95\%), sedangkan yang belum tuntas belajar ada 14 siswa (21,05\%). Berdasarkan hasil pengamatan, pengisian angket, dan hasil evaluasi dalam Siklus I, maka kegiatan pembelajaran dapat direfleksikan sebagai berikut:

1) Pada awal siklus pertama, pada saat guru menyampaikan tentang penggunaan metode dan ketentuannya, kondisi siswa masih diliputi rasa ketegangan. 
2) Pada saat guru membentuk kelompok pada pertemuan pertama, kondisi siswa cukup gaduh. Ada yang tidak setuju dengan anggota kelompoknya. Namun setelah mendapat penjelasan guru, siswa dapat menerima.

3) Di antara kelompok ada yang merasa kekurangan buku sumber, sehingga kesulitan mencari jawaban.

4) Guru memberikan bimbingan kepada empat kelompok.

5) Pada pertemuan pertama, guru memberikan tugas tambahan kepada 2 kelompok, yaitu kelompok 3 dan kelompok 6. Laporan dilakukan secara individu. Guru juga memberikan tugas secara individu 2 siswa dari kelompok 1, dan 3 siswa dari kelompok 5.

6) Pada pertemuan berikutnya tugas secara kelompok sudah tidak ada, namun tugas tambahan secara individu masih ada 9 siswa.

7) Pada saat presentasi, situasi kelas didominasi oleh beberapa anak saja.

8) Pada pertemuan pertama, waktu untuk diskusi kurang. Sehingga guru harus menghentikan proses presentasi.

9) Pada pertemuan kedua dan ketiga pengaturan waktu sudah cukup baik.

10) Guru mengajak siswa untuk menyusun kesimpulan.

11) Perencanaan yang dilakukan oleh guru sudah baik, yaitu memperoleh skor 17 (85\%) dari skor maksimal 20.

12) Kegiatan belajar mengajar yang dilakukan oleh guru sudah baik, yaitu memperoleh skor $19(79,17 \%)$ dari skor maksimal 24.

13) Aktivitas belajar siswa masih kurang baik, yaitu memperoleh skor 18 $(64,29 \%)$ dari skor maksimal 28.

14) Respons siswa terhadap kegiatan belajar mengajar sudah cukup baik, yaitu dengan memperoleh skor mean 2,79 atau sebesar 69,74 \%.

15) Hasil belajar siswa secara klasikal belum tuntas, yaitu $78,95 \%$ siswa yang sudah tuntas belajar.

Berdasarkan hasil refleksi tersebut, dan berbagai pertimbangan dari observer/kolaborator, maka yang perlu diperhatikan oleh guru dalam siklus berikutnya adalah perencanaan hendaknya lebih ditingkatkan. Pelaksanaan pembelajaran yang dilakukan oleh guru hendaknya lebih ditingkatkan. Guru hendaknya dapat memberikan alternatif materi sebagai acuan untuk memecahkan permasalahan. Guru hendaknya dapat membagi rata diantara siswa yang berpartisipasi pada saat presentasi oleh kelompok. Guru hendaknya lebih mendorong siswa untuk dapat melakukan kerja kelompok. Bimbingan guru harus lebih intensif untuk menumbuhkan motivasi siswa.

\section{Siklus II}

Pelaksanaan tindakan yang dilakukan pada Siklus II terdiri dari tiga kali pertemuan, yang masing-masing pertemuan menggunakan waktu 90 menit. Jadi dalam Siklus I menggunakan waktu 270 menit. Pelaksanaan tindakan dalam Siklus II dilaksanakan dalam tiga kali pertemuan. Secara rinci pelaksanaannya sebagai berikut:

Kegiatan awal (15 menit) 
- Guru mengadakan presensi kelas.

- Guru menjelaskan tujuan pembelajaran setiap pertemuan dalam Siklus II.

- Guru selalu menjelaskan metode yang digunakan pada setiap pertemuan dalam Siklus II.

- Guru memberikan motivasi kepada siswa dalam mengikuti kegiatan belajar mengajar pada setiap pertemuan dalam Siklus II.

- Guru mengadakan apersepsi dalam setiap pertemuan pada Siklus II.

Kegiatan Inti (210 menit)

- Guru memberikan tugas yang berbeda kepada masing-masing kelompok.

- Siswa melakukan kerja kelompok.

- Guru membimbing siswa dalam kerja kelompok.

- Guru mengamati siswa, baik secara individu maupun secara kelompok.

- Guru menunjuk salah satu kelompok untuk melakukan presentasi.

- Guru membimbing siswa dalam melakukan presentasi.

- Kelompok yang lain memberikan tanggapan secara bergiliran.

- Guru memberikan tugas secara individu.

Kegiatan akhir (15 menit)

- Bersama-sama dengan siswa, guru membuat kesimpulan dalam setiap pertemuan dari kegiatan pembelajaran yang telah dilakukan.

Pengamatan

Hasil pengamatan yang dilakukan oleh observer dan guru dapat dilihat dalam tabel sebagai berikut:

Tabel 5. Rekapitulasi Hasil Observasi Kegiatan Guru Siklus II

\begin{tabular}{|c|l|c|c|}
\hline \multirow{2}{*}{ No } & \multirow{2}{*}{ Kegiatan } & \multicolumn{2}{|c|}{ Siklus II } \\
\cline { 3 - 4 } & & Jml & \% \\
\hline 1 & Perencanaan Pembelajaran & 19 & 95 \\
\hline 2 & Pelaksanaan Pembelajaran & 21 & 87,5 \\
\hline
\end{tabular}

Kegiatan pengamatan terhadap aktivitas siswa dilakukan oleh guru maupun observer/pengamat pada saat siswa melakukan diskusi. Berdasarkan rekapitulasi hasil kuesioner respons siswa terhadap kegiatan belajar mengajar pada Siklus II, dapat diketahui prosentase respons siswa dalam pembelajaran sebagaimana dalam tabel berikut ini: 
Tabel 6. Prosentase Hasil Kuesioner Respons Siswa Terhadap Kegiatan Belajar Mengajar Pada Siklus II

\begin{tabular}{|c|l|r|r|r|}
\hline No & \multicolumn{1}{|c|}{ Keterangan } & \multicolumn{1}{c|}{ Jumlah } & \multicolumn{1}{c|}{ \% } & \multicolumn{1}{c|}{ Skor Mean } \\
\hline 1 & Tidak senang & 0 & 0 & 0 \\
\hline 2 & Kurang senang & 5 & 13,16 & 0,26 \\
\hline 3 & Senang & 24 & 63,16 & 1,89 \\
\hline 4 & Senang Sekali & 9 & 23,68 & 0,95 \\
\hline \multicolumn{2}{|r|}{ Jumlah } & 38 & 100 & 3,11 \\
\hline
\end{tabular}

Hasil evaluasi pada Siklus II, siswa yang sudah tuntas belajar ada 17 siswa $(86,84 \%)$, sedangkan yang belum tuntas belajar ada 3 siswa $(13,16 \%)$.

Refleksi

Berdasarkan hasil pengamatan, pengisian angket, dan hasil evaluasi dalam Siklus II, maka kegiatan pembelajaran dapat direfleksikan sebagai berikut:

1) Kondisi siswa sudah terlihat kondusif.

2) Guru memberikan bimbingan kepada dua kelompok.

3) Tugas tambahan diberikan kepada individu, secara kelompok sudah tidak ada.

4) Pada saat presentasi, situasi kelas masih didominasi oleh beberapa anak saja.

5) Pengaturan waktu sudah semakin baik.

6) Pada pertemuan kedua dan ketiga pengaturan waktu sudah cukup baik.

7) Guru mengajak siswa untuk menyusun kesimpulan.

8) Perencanaan yang dilakukan oleh guru sudah sangat baik, yaitu memperoleh skor 19 (95\%) dari skor maksimal 20.

9) Kegiatan belajar mengajar yang dilakukan oleh guru juga sangat baik, yaitu mem-peroleh skor $21(87,5 \%)$ dari skor maksimal 24 .

10) Aktivitas belajar siswa sudah baik, yaitu memperoleh skor $23(82,14 \%)$ dari skor maksimal 28.

11) Respons siswa terhadap kegiatan belajar mengajar sudah baik, yaitu dengan memperoleh skor mean 3,11 atau sebesar 77,11\%.

12) Hasil belajar siswa secara klasikal sudah tuntas, yaitu $86,84 \%$ siswa yang sudah tuntas belajar.

Berdasarkan hasil refleksi tersebut, dan berbagai pertimbangan dari observer/kolaborator, maka yang perlu diperhatikan oleh guru dalam siklus berikutnya adalah kegiatan guru sudah dilaksanakan dengan sangat baik. Guru hendaknya lebih mendorong siswa untuk dapat mempersiapkan diri dengan lebih baik lagi dalam kegiatan belajar mengajar. Bimbingan guru harus lebih intensif untuk menumbuhkan motivasi siswa. Berdasarkan hasil observasi, pengisian angket oleh siswa, dan hasil tes yang dilakukan pada pra tindakan, Siklus I dan Siklus II, dapat diketahui bahwa aktivitas belajar siswa, berdasarkan tabel di atas dapat diuraikan bahwa rata-rata prosentase pada Siklus I sebesar 64,84\%. Namun dalam Siklus II, aktivitas belajar siswa 
mengalami peningkatan, yaitu menjadi $82,145 \%$. Jadi aktivitas belajar siswa sudah baik.

Hasil kuesioner respons siswa terhadap kegiatan belajar mengajar menunjukkan bahwa kualifikasi yang menyatakan tidak senang sudah tidak ada, baik pada Siklus I maupun pada Siklus II. Sedangkan yang menyatakan kualifikasi kurang senang menunjukkan penurunan dari 13 siswa (34,21\%) pada Siklus I, menjadi 5 siswa $(13,16 \%)$ pada Siklus II. Kualifikasi yang menyatakan senang mengalami kenaikan dari 20 siswa $(52,63 \%)$ pada Siklus I, menjadi 24 siswa $(63,16 \%)$ pada Siklus II. Kualifikasi yang menyatakan sangat senang mengalami kenaikan dari 5 siswa $(13,16 \%)$ pada Siklus I, menjadi 9 siswa $(23,68 \%)$ pada Siklus II. Sedangkan jumlah mean menunjukkan kenaikkan dari 2,79 (69,74\%) pada Siklus I, menjadi 3,11 (77,11\%) pada Siklus II.

Peningkatan kegiatan guru dan aktivitas belajar siswa juga berpengaruh terhadap hasil evaluasi. Hasil evaluasi menunjukkan terdapat kenaikkan yang tuntas belajar dari 25 siswa $(65,79 \%)$ pada pra tindakan menjadi 30 siswa (78,95\%) pada Siklus I, dan menjadi 33 siswa (86,84\%) pada Siklus II. Sedangkan yang belum tuntas belajar mengalami penurunan dari 13 siswa $(34,21 \%)$ pada pra tindakan menjadi 8 siswa $(21,05 \%)$ pada Siklus I, dan menjadi 5 siswa $(13,16 \%)$ pada Siklus II.

\section{PENUTUP}

Berdasarkan hasil analisis data dan pembahasan hasil penelitian dapat ditarik kesimpulan bahwa perencanaan pembelajaran, ada peningkatan dari $85 \%$ pada Siklus I menjadi $95 \%$ pada Siklus II. Jadi perencanaan pembelajaran yang dilakukan oleh guru sangat baik. Sedangkan pelaksanaan pembelajaran yang dilakukan oleh guru juga mengalami pengingkatan dari $79,17 \%$ pada Siklus I menjadi $87,50 \%$ pada Siklus II. Jadi pelaksanaan pembelajaran yang dilakukan oleh guru juga sangat baik.

Aktivitas belajar siswa mengalami peningkatan, pada Siklus I sebesar 64,84\%, Sedangkan dalam Siklus II menjadi 82,145\%. Respons siswa terhadap kegiatan belajar mengajar dapat diuraikan sebagai berikut:

- Kualifikasi yang menyatakan tidak senang sudah tidak ada, baik pada Siklus I maupun pada Siklus II.

- Sedangkan yang menyatakan kualifikasi kurang senang menunjukkan penurunan dari 13 siswa $(34,21 \%)$ pada Siklus I, menjadi 5 siswa $(13,16 \%)$ pada Siklus II.

- Kualifikasi yang menyatakan senang mengalami kenaikan dari 20 siswa $(52,63 \%)$ pada Siklus I, menjadi 24 siswa $(63,16 \%)$ pada Siklus II.

- Kualifikasi yang menyatakan senang sekali mengalami kenaikan dari 5 siswa $(13,16 \%)$ pada Siklus I, menjadi 9 siswa $(23,68 \%)$ pada Siklus II.

Hasil evaluasi menunjukkan terdapat kenaikkan yang tuntas belajar dari 25 siswa $(65,79 \%)$ pada pra tindakan menjadi 30 siswa $(78,95 \%)$ pada Siklus I, dan menjadi 33 siswa $(86,84 \%)$ pada Siklus II. Sedangkan yang belum tuntas 
belajar mengalami penurunan dari 13 siswa (34,21\%) pada pra tindakan menjadi 8 siswa $(21,05 \%)$ pada Siklus I, dan menjadi 5 siswa $(13,16 \%)$ pada Siklus II. Hipotesis tindakan yang menyatakan bahwa "jika strategi Injeksi digunakan dalam pembelajaran mata pelajaran IPS, maka aktivitas belajar siswa kelas IV SD Negeri 028228 Binjai akan meningkat", dapat diterima.

Berdasarkan uraian di atas, maka dapat disampaikan kepada para guru diharapkan dapat semakin aktif dan kreatif dalam memilih metode dalam kegiatan belajar mengajar agar dapat meningkatkan prestasi belajar siswa. Kepada Kepala Sekolah hendaknya dapat mengambil kebijakan tentang perlunya melaksanakan Penelitian Tindakan Kelas (PTK) bagi setiap guru, agar aktivitas belajar siswa juga semakin meningkat. Kepada Kepala Sekolah hendaknya dapat mengusahakan agar ketersediaan sarana bagi para guru dalam melaksanakan PTK terus ditingkatkan. Sehingga penelitian tindakan kelas menjadi budaya bagi warga sekolah.

\section{REFERENSI}

Arikunto, Suharsimi, Suhardjono, Supardi. (2006). Penelitian Tindakan Kelas. Jakarta: PT Bumi Aksara.

Departemen Pendidikan Nasional. (2005). Materi Pelatihan Terintegrasi Pengetahuan Sosial, Buku 1. Jakarta: Direktorat Pendidikan Lanjutan Pertama

Hamalik, Oemar. (1992). Psikologi Belajar dan Mengajar. Bandung: Sinar Baru. Ischak. (2002). Pendidikan IPS di SD. Jakarta: Pusat Penerbitan Universitas Terbuka.

Kementerian Pendidikan Nasional. (2010). Bahan Pelatihan Pengembangan Pendidikan Budaya dan Karakter Bangsa.

Miarsa, Yusufhadi. (1995). Peningkatan Mutu Pendidikan, Jurnal Teknologi Pembelajaran. Malang: IPTPI.

Mulyasa, E. (2005). Menjadi Guru Profesional, Menciptakan Pembelajaran Kreatif dan Menyenangkan. Bandung: PT Remaja Rosdakarya Offset.

Nazir, Moh. (1988). Metode Penelitian. Jakarta: Ghalia Indonesia.

Rachman, Saiful, Yoto, Syarif Suhartadi, Suparti. (2006). Penelitian Tindakan Kelas dan Penulisan Karya Ilmiah. Surabaya: SIC Bekerjasama Dengan Dinas P dan K Provinsi Jawa Timur.

Soetomo. (1993). Dasar-dasar Interaksi Belajar Mengajar. Surabaya: Usaha Nasional.

Yayasan Jati Diri Bangsa. (2008). Membangun Kembali Jati Diri Bangsa. Jakarta: Penerbit PT Elex Media Komputindo Kompas Gramedia.

Zaini, Hisyam, Bermawy Munthe, Sekar Ayu Aryani. (2004). Strategi Pembelajaran Aktif. Yogyakarta: CTSD. 